\title{
EHMTI-0131. Clinical features of cluster headache in women
}

\author{
C Tassorelli $i^{*}$, Y Falzone ${ }^{2}$, R De Icco ${ }^{2}$, MG Cuzzoni ${ }^{2}$, G Nappi ${ }^{2}$, G Sances ${ }^{2}$ \\ From 4th European Headache and Migraine Trust International Congress: EHMTIC 2014 \\ Copenhagen, Denmark. 18-21 September 2014
}

\section{Introduction}

Cluster Headache $(\mathrm{CH})$ mostly affects men but a substantial percentage of women also suffer this headache disorder. Little is known about possible gender-related differences in the characteristics of attacks from studies where $\mathrm{CH}$ diagnosis was validated.

\section{Aim}

To evaluate retrospectively the differences in demographics, headache characteristics, concomitant diseases and treatment response of $198 \mathrm{CH}$ patients diagnosed and followed at the Pavia Headache Centre.

\section{Results}

Data from 134 males and 64 females were collected. The mean age at $\mathrm{CH}$ onset was lower in women than in men $(24.8 \pm 10.8 y$ vs $28.03 \pm 10.2 y, p<0.43)$. Episodic form of the disease was diagnosed in $91 \%$ of subjects, without gender difference. No differences were detected as regards the annual mean number of $\mathrm{CH}$ periods, their mean duration and the average daily frequency of attacks during the active phase. Untreated attacks were shorter in men (90 minutes vs 107 minutes, $\mathrm{p}<0.02$ ). A family history of migraine was present in $71.4 \%$ of women and $59.1 \%$ of men $(\mathrm{p}=0.06)$. Nausea, vomiting, photo and osmophobia were reported more frequently by women than men, while local autonomic symptoms were almost equally distributed between sexes. No difference was found in treatment response between genders. Female $\mathrm{CH}$ sufferers presented more frequently thyroid disorders and psychiatric illness than men. On the contrary, snoring in sleep occurred statistically more frequently in men.

'Headache Science Center C. Mondino National Neurological Institute, Dept of Brain and Behaviour University of Pavia, Pavia, Italy

Full list of author information is available at the end of the article

\section{Conclusions}

This retrospective survey shows some specific features for $\mathrm{CH}$ in women: earlier onset of disease, more frequent association with 'migrainous' symptoms during the attacks and a longer duration of untreated attacks.

\section{Authors' details}

${ }^{1}$ Headache Science Center C. Mondino National Neurological Institute, Dept of Brain and Behaviour University of Pavia, Pavia, Italy. ${ }^{2}$ Headache Science Center, C. Mondino National Neurological Institute, Pavia, Italy.

Published: 18 September 2014

doi:10.1186/1129-2377-15-S1-C3

Cite this article as: Tassorelli et al:: EHMTI-0131. Clinical features of cluster headache in women. The Journal of Headache and Pain 2014 15(Suppl 1):C3.

\section{SpringerOpen ${ }^{\odot}$}

(C) 2014 Tassorelli et al; licensee Springer. This is an Open Access article distributed under the terms of the Creative Commons Attribution License (http://creativecommons.org/licenses/by/2.0), which permits unrestricted use, distribution, and reproduction in any medium, provided the original work is properly cited.
Submit your manuscript to a SpringerOpen ${ }^{\circ}$ journal and benefit from:

- Convenient online submission

- Rigorous peer review

- Immediate publication on acceptance

- Open access: articles freely available online

- High visibility within the field

Retaining the copyright to your article

Submit your next manuscript at $>$ springeropen.com 